\title{
EXTENDING THE PRESUMPTION OF DECISIVE INFLUENCE TO IMPUTE PARENTAL LIABILITY TO PRIVATE EQUITY FIRMS FOR THE ANTICOMPETITIVE CONDUCT OF PORTFOLIO COMPANIES
}

\author{
VASILIKI FASOULA*
}

The private equity firms' goal is to increase the profitability of their portfolio companies, run them up to an initial public offering and exit them. This includes improvements in corporate governance and management practices. The operational economic model of private equity firms is that of financial investors and not that of industrial owners of subsidiaries. However, this economic distinction makes no legal difference when engaging a company's parental liability for the anticompetitive behaviour of its subsidiaries under the European competition law provisions. This was the case when, on 27 January 2021, the Court of Justice of the European Union rejected the Goldman Sachs Group's appeal against a judgment of the General Court of the European Union validating the fine the Commission had imposed for the participation of one of its indirectly owned subsidiaries in a cartel during the period it was under Goldman Sachs' control. For the first time, the Court extended the presumption of the effective exercise of decisive influence to the majority of the voting rights, and any involvement in the day-to-day business of the portfolio company was further proof of this actual exercise. Revitalising the debate of the fundamentals of parental liability in competition law and juxtaposing the differences between European and American legal tradition, the Goldman Sachs case leaves no choice to equity firms but to take strict measures and to harden the negotiations before any acquisition takes place, boping to escape the strict application of the single economic entity doctrine.

\section{INTRODUCTION}

On 27 January 2021, the Court of Justice of the European Union (“CJEU”) adopted a judgement ${ }^{1}$ rejecting the Goldman Sachs Group's ("Goldman Sachs") appeal seeking to set aside the judgment of the General Court of the European Union ("GCEU”) of 12 July $2018 .{ }^{3}$ The GCEU had dismissed the Goldman Sachs' action seeking, firstly, the annulment of the

\footnotetext{
* PhD candidate in Competition Law, University Paris II Panthéon-Assas, Research Institute in Business Law. Teaching and Research Assistant (A.T.E.R) in Private Law, University Paris Nanterre. For correspondence : <vicky_fasoula@hotmail.com>.

${ }^{1}$ Case C-595/18 P The Goldman Sachs Group Inc. v European Commission [2021] ECLI:EU:C:2021:73.

2 According to the Group's website, the Goldman Sachs Group, Inc. is a leading global financial institution that delivers a broad range of financial services across investment banking, securities, investment management and consumer banking to a large and diversified client base that includes corporations, financial institutions, governments and individuals. Founded in 1869, the firm is headquartered in New York and maintains offices in all major financial centers around the world. < https://www.goldmansachs.com/> accessed 27 February 2021.

${ }^{3}$ Case T-419/14 The Goldman Sachs Group, Inc. v European Commission [2018] ECLI:EU:T:2018:445.
} 
European Commission's ("EC") Decision" imposing a fine to Goldman Sachs for the participation of one of its indirectly owned subsidiaries in the power cable cartel during the period it was under Goldman Sachs' control and, secondly, a reduction of the fine imposed on it. The CJEU confirmed the fine of EUR 37,303,000 million imposed to Goldman Sachs on a joint and several basis. Despite the fact that the investor was left with a minority stake in the subsidiary after an initial public offering ("IPO"), the CJEU upheld the investor's parental liability. The totality of voting rights attached to the minority stake, as well as a sufficient representation of the holding at the board of directors and a management oversight of its subsidiary were, according to the CJEU, evidence of the holding's decisive influence over the subsidiary's economic and commercial policy. The judgment is of major interest to private equity funds and other financial investors, whose business mainly consists of buying and selling stakes in other companies under a purely financial investment perspective. They need to implement strategies to ensure that they might not be found liable under the European Union ("EU") competition law provisions for any anticompetitive practices of their portfolio companies.

\section{FACTS}

Between 29 July 2005 and 28 January 2009 Goldman Sachs was the parent company indirectly, through its private equity portfolio manager GS Capital Partners V Funds and other intermediary companies, of Prysmian SpA ("Prysmian") and its wholly owned subsidiary Prysmian Cavi e Sistemi Sri ("Prysmian CS") world leading players in the submarine and underground power cables sector. The EC found that Prysmian and Prysmian CS were members of a cartel that was in place from February 1999 to the end of January 2009 between the main European, Japanese and South Korean producers of submarine and underground power cables that allocated markets and customers, thereby distorting the normal competitive process. Goldman Sachs initially held 100\% of the shares in Prysmian for 41 days. Its holding was then gradually reduced, on 7 September 2005 and then again on 21 July 2006 to $91.1 \%$ and 84.4\% respectively, until 3 May 2007, date of the IPO on the Milan Stock Exchange (pre-IPO period). After the IPO and until 28 January 2009, Goldman Sachs' shares fell to $31.69 \%$ (post-IPO period).

On 2 April 2014, the EC found Prysmian and Prysmian CS, amongst others, liable for the infringement of Article 101 of the Treaty on the Functioning of the European Union ("TFEU") ${ }^{5}$ for their involvement in a cartel in the power cables sector. Despite the fact that there were no evidence that Goldman Sachs knew or encouraged the subsidiary's participation in the cartel, it was held jointly and severalty liable for EUR 37,303,000 million of the EUR 104,613,000 million fine imposed on Prysmian, proportional to its four-year investment at it, between 29 July 2005 and 28 January 2009. The EC based its decision on the following grounds: (i) a presumption that Goldman Sachs exercised a decisive influence

\footnotetext{
${ }^{4}$ Power Cables (Case AT.39610) Commission Decision relating to a proceeding under Article 101 of the Treaty on the Functioning of the European Union and Article 53 of the EEA Agreement C(2014) 2139 final [2014] OJ C/319.

${ }^{5}$ Consolidated versions of the Treaty on European Union and the Treaty on the Functioning of the European Union - Consolidated version of the Treaty on the Functioning of the European Union - Protocols - Annexes - Declarations annexed to the Final Act of the Intergovernmental Conference which adopted the Treaty of Lisbon, signed on 13 December 2007 - Tables of equivalences [2012] OJ C/326.
} 
over Prysmian's and thus Prysmian CS's behaviour on the market and (ii) according to the analysis of the economic, organisational and legal links with these companies, Goldman Sachs actually did exercise a decisive influence over Prysmian's behaviour and consequently over Prysmian CS.

3 THE JUDGMENT OF THE GCEU OF 12 JULY 2018 IN CASE T-419/14 THE GOLDMAN SACHS GROUP INC. V EUROPEAN COMMISSION

Goldman Sachs has brought an appeal against the EC's decision before the GCEU, seeking its annulment and/or a reduction of the fine. The appeal was dismissed. The presumption of exercising a decisive influence was rightly upheld by the EC. Although Goldman Sachs' holding in Prysmian was not 100\% during the whole of the relevant period, the GCEU held that the position of a parent company that holds all the voting rights attached to the shares of its subsidiary, combined with a very high majority holding in its subsidiary's capital, as was the case here during the pre-IPO period, is similar to the position of a single shareholder of that subsidiary. It could be therefore presumed that the parent company determines the economic and business strategy of the subsidiary, even if it does not hold all or almost all of the subsidiary's share capital. ${ }^{6}$ During the post-IPO period, although Goldman Sachs was left with a minority share of $31,69 \%$ the GCEU found that it actually did exercise decisive influence as it had management oversight of Prysmian and Prysmian CS through its powers to (i) appoint the members of Prysmian's boards of directors, (ii) call Prysmian's shareholder meetings, (iii) propose the removal of board members or of all boards of directors of Prysmian, (iv) have a relevant role in the boards of directors and (v) receive regular updates and monthly reports from Prysmian.

\section{THE JUDGMENT OF THE CJEU OF 27 JANUARY 2021 IN CASE C-595/18 P THE GOLDMAN SACHS GROUP INC V EUROPEAN COMMISSION}

In its appeal to the CJEU, Goldman Sachs relied on two grounds to claim that the GCEU was wrong to find that the EC had correctly applied Article 101 TFEU and Article 23(2) of Regulation $1 / 2003^{8}$ to find Goldman Sachs liable for an infringement committed by Prysmian and Prysmian CS: (i) that the presumption of decisive influence, as established in Akzo, applies only to wholly owned subsidiaries, thus it should not have been taken into consideration for the pre-IPO period; (ii) that there was an error in law regarding the elements taken into consideration to establish that Goldman Sachs actually did exercise decisive influence within the meaning required by EU established case-law for the post-IPO period. The appellant also claimed that the CJEU should extend to it the benefit of any fine reduction granted to Prysmian and Prysmian CS, by reducing the amount of the fine imposed

\footnotetext{
${ }^{6}$ Case C-595/18 P The Goldman Sachs Group Inc. v European Commission [2021] ECLI:EU:C:2021:73, para 17.

${ }^{7}$ Case C-595/18 P The Goldman Sachs Group Inc. v European Commission [2021] ECLI:EU:C:2021:73, para 18.

${ }^{8}$ Council Regulation (EC) No 1/2003 of 16 December 2002 on the implementation of the rules on

competition laid down in Articles 81 and 82 of the Treaty (Text with EEA relevance) [2003] OJ L/1.

${ }^{9}$ Case C-97/08 P Akzo Nobel NV and Others v Commission of the European Communities [2003]

ECLI:EU:C:2009:536.
} 
jointly and severally on it and Prysmian and Prysmian CS, in the event that the CJEU upholds the appeal brought by those companies against the EC's Decision on the power cable cartel case. $^{10}$

The CJEU dismissed Goldman Sachs' appeal in its entirety. The EC has constantly relied on the rebuttable presumption that a parent company has decisive influence over the strategy of its subsidiaries when it holds the totality or the almost totality of the subsidiary's capital. In the present case, the CJEU recognised that even though Goldman Sachs did not hold 100\% of Prysmian's capital during the entire pre-IPO period, it held, however, the totality of the voting rights. The CJEU held that the GCEU did not err when upholding that a parent company which holds all the voting rights associated with its subsidiary's shares is, in that regard, in a similar situation to that of a parent company holding all or virtually all the capital of the subsidiary, so that the parent company is able to determine the subsidiary's economic and commercial strategy. ${ }^{11}$ It also reaffirmed that the burden of rebutting this presumption fell on Goldman Sachs who, however, had failed do so. ${ }^{12}$ Because of Goldman Sachs' presumed actual exercice of decisive influence through the voting rights, the CJEU equated Goldman Sachs with an industrial owner of Prysmian instead of attributing a pure financial investor role to Goldman Sachs. ${ }^{13}$ The EU competition law does not attach parental liability, for the breach committed by a subsidiary, to pure financial investors, i.e. investors who hold shares in a company in order to make a profit, but who refrain from any involvement in its management and its control. For the CJEU, the element of a pure financial investor does not constitute a legal criterion, which would mean that the EC would have to bear the burden of proof, but is an example of a circumstance in which it is open to a parent to rebut the presumption of the actual exercise of decisive influence. ${ }^{14}$

For the post-IPO period, the CJEU upheld that there was no error in law committed by the GCEU when evaluating a body of consistent evident regarding the economic, organisational and legal links tying the subsidiary to its parent, even if some of that evidence, taken in isolation, is insufficient to establish the existence of decisive influence. That body of evidence may include elements relating to a period prior to the infringement as long as the relevance of these elements to the period of the infringement can be established. ${ }^{15}$ Furthermore, the existence of decisive control may be demonstrated through a formal relationship between the parent and the subsidiary but also through informal relationships, consisting, inter alia, in examining personal links between the legal entities comprising the economic unit formed by the parent company and its subsidiary. This may happen for example, in cases where a person who sits on the board of directors of a subsidiary is connected to the parent company by means of previous advisory services or consultancy agreements. ${ }^{16}$

\footnotetext{
${ }^{10}$ Case T-475/14 Prysmian and Prysmian Cavi e Sistemi v Commission [2018] ECLI:EU:T:2018:448.

${ }^{11}$ Case C-595/18 P The Goldman Sachs Group Inc. v European Commission [2021] para 35.

12 Case C-595/18 P The Goldman Sachs Group Inc. v European Commission [2021] paras 36-41.

${ }^{13}$ Case C-595/18 P The Goldman Sachs Group Inc. v European Commission [2021] paras 45-47.

${ }^{14}$ Case T-419/14 The Goldman Sachs Group, Inc. v European Commission [2018] para 151; Case T-392/09 1. garantovaná a.s. v European Commission [2012] ECLI:EU:T:2012:674 paras 50-52.

${ }_{15}$ Case C-595/18 P The Goldman Sachs Group Inc. v European Commission [2021] paras 67-68.

${ }^{16}$ Case C-595/18 P The Goldman Sachs Group Inc. v European Commission [2021] paras 93-94.
} 


\section{SIGNIFICANCE OF THE CJEU'S JUDGEMENT}

\subsection{THE PARTICULAR RELATIONSHIP BETWEEN EQUITY FIRMS AND PORTFOLIO COMPANIES}

A private equity firm is a group of investment professionals that raises money from investors and pools it in one or more investment vehicles, the private equity funds, for the purpose of engaging in private equity. The companies that private equity firms acquire are their portfolio companies. The private equity firm's main strategy is to take control of a portfolio company for a limited period of time, to increase the company's profitability, run it up to an IPO and then exit the company. ${ }^{17}$ In the United States ("US") private equity ownership is very common. Until the late 70s', private equity investments were undertaken by wealthy families, industrial corporations and financial institutions that invested directly in issuing firms. The US regulatory and tax changes in the 80s' allowed this activity to grow and to be undertaken by professional private equity managers on behalf of institutional investors. This was possible through a limited partnership were the institutional investors, like Goldman Sachs, are the limited partners and the investment managers are the general partners. ${ }^{18}$ While private equity ownership is also increasing in Europe, so is the criticism against private equity firms from trade unions and some members of the European Parliament accusing them of profiting off of companies' asset-stripping, of instigating restructurings with negative impacts on employment and of using leverage and off-shore holding companies to reduce tax charges. ${ }^{19}$

Many studies have shown that there are, generally, three ways in which private equity ownership can increase the profitability of portfolio companies: (i) there can be a more effective use of debt and other financial instruments; the private equity's established reputation with creditors in the debt market reduces portfolio companies' cost of debt capital giving them a borrowing advantage over other companies; ${ }^{20}$ (ii) an improvement of firmlevel productivity is possible through efficient reallocations of labour and capital; (iii) value can be created through better corporate governance and management practices. ${ }^{21}$ Private equity firms regularly replace top management, both before and after they invest in a company. They also set up small boards of directors with a mix of portfolio company's insiders, outsiders and private equity investors. ${ }^{22}$ The private equity firm exercise control over portfolio companies through their representation on the companies' board of directors. The chief executive officers ("CEOs") of portfolio companies are not members of the private

\footnotetext{
${ }^{17}$ Steven Kaplan, Per Strömberg, "Leveraged Buyouts and Private Equity” [2009] J.Econ.Persp. 121.

${ }_{18}$ George Fenn, Nellie Liang, Stephen Prowse, "The Economics of the Private Equity Market" [1996] Fed.

Res. Bull. 26; Helen Kenyon (ed), 'Preqin Special Report: Banks as Investors in Private Equity' (2012)

$<$ https://docs.preqin.com/reports/Preqin_Special_Report_Banks_as_Investors_in_Private_Equity.pdf $>$ accessed 27 February 2021.

${ }^{19}$ Mike Wright, Kevin Amess, Charlie Weir, et al. "Private equity and corporate governance: Retrospect and prospect" [2009] Corporate Governance: An International Review 353.

${ }^{20}$ Elisabeth De Fontenay, "Private equity firms as gatekeepers" [2013] Rev. Banking \& Fin. L. 115.

${ }^{21}$ Nicholas Bloom, Raffaella Sadun, John Van Reenen, "Do private equity owned firms have better management practices?” [2015] American Economic Review 442.

22 Paul Gompers, Steven Kaplan, Vladimir Mukharlyamov, "What do private equity firms say they do?" [2016] Journal of Financial Economics 449.
} 
equity firms' management, and the operating managers of these companies are more autonomous than unit managers in public companies. ${ }^{23}$

\subsection{THE US LIABILITY REGIME FOR ANTITRUST INFRINGEMENTS COMMITTED BY A SUBSIDIARY}

In the US, a company can only be personally liable for the legal infringements it has committed. In cases involving parent companies and subsidiaries, the corporate separateness generally prevails and any imputation of liability to another legal entity other than the one that committed the infringement is only used as an "extreme remedy." ${ }^{4}$ In these extreme cases, there are three traditional methods of holding parent companies liable for the infringements of their subsidiaries: imputing liability via agency law principles, imputing liability by means of piercing the corporate veil, ${ }^{25}$ and imputing liability through standard inducement principles, which means that the parent must have known, encouraged or actively contributed to the subsidiary's infringement. ${ }^{26}$ The same applies to US federal antitrust enforcement which is both criminal and civil in nature. In criminal cases, the government must prove the direct involvement of the parent company to the antitrust infringement of its subsidiary. In antitrust suits, parent liability will be attached to the company if it was actively involved in the antitrust violation or if the criteria for piercing the subsidiary's corporate veil can be met by a plaintiff. ${ }^{27}$ In a recent case, involving a private equity firm, Lion Capital, the District Court for the Southern District of California ruled that the firm must face trial in class action litigation alongside its portfolio company, Bumble Bee Seafoods, in a case concerning price-fixing in the market of canned tuna. ${ }^{28}$ The plaintiffs claimed that the firm discovered the subsidiary's role in the price-fixing conspiracy during its acquisition in 2010 and proceeded with the transaction in an attempt to reap supracompetitive profits. They further claimed to have detailed evidence of the investor's direct involvement in the conspiracy.

\subsection{THE EU LIABILITY REGIME FOR ANTITRUST INFRINGEMENTS COMMITED BY A SUBSIDIARY}

In Europe, instead of a direct or indirect involvement in the infringement, the liability of the parent for the anticompetitive behaviour of its subsidiary is attached to the notion of control and to the single economic undertaking rationale. ${ }^{29}$ The first case where a parent company

\footnotetext{
${ }^{23}$ Felix Barber, Michael Goold, “The Strategic Secret of Private Equity” [2007] Harvard Business Review 53; Ulrich Lossen, Portfolio Strategies of Private Equity Firms-Theory and Evidence, (Deutscher Universitäts-Verlag 2007).

${ }^{24}$ Sonora Diamond Corp. V. Superior Court [2000] 83 Cal. App. 4th 523, 539.

25 Traditional "piercing" jurisprudence rests on a demonstration of three fundamental elements: the subsidiary's lack of independent existence; the fraudulent, inequitable, or wrongful use of the corporate form; and a causal relationship to the plaintiff's loss. Unless each of these three elements has been shown, courts have traditionally held "piercing" unavailable, see John Matheson, "The modern law of corporate groups: An empirical study of piercing the corporate veil in the parent-subsidiary context" [2008] NCL Rev. 1091. ${ }^{26}$ Emma Tracy, "Imputed Liability: How to Determine When Parent Companies Should Be Held Liable for the Patent Infringements of Their Subsidiary Companies” [2017] Mo. L. Rev. 82.

${ }^{27}$ Carsten Koening, "Comparing Parent Company Liability in EU and US Competition Law" [2018] World Competition 70 .

${ }^{28}$ Case No.: 15-MD-2670 JLS (MDD) In re Packaged Seafood Products Antitrust Litigation [2018] United States District Court, S.D. California, 338 F.Supp.3d 1118.

${ }^{29}$ According to EU case-law "in certain circumstances, a legal person who is not the perpetrator of an infringement of the competition rules may nevertheless be penalised for the unlawful conduct of another legal person, if both those persons form part of the same economic entity", see Joined Cases C-231/11 P to C-233/11 P European Commission v Siemens AG
} 
was held liable for the anticompetitive behaviour of its subsidiaries was in 1969 where the parent was found to have given explicit directions to its subsidiaries to raise the prices. ${ }^{30}$ The parent company lodged an appeal and the CJEU upheld that the fact that a subsidiary has separate legal personality is not sufficient to exclude the possibility of imputing its conduct to the parent company. Such may be the case in particular where the subsidiary, although having separate legal personality, does not decide independently upon its own conduct on the market but carries out, in all material respects, the instructions given to it by the parent company with which it forms one economic unit. ${ }^{31}$ The lack of autonomy and the rebuttable presumption of decisive influence of the parent to the subsidiary was upheld in AEG Telefunken, ${ }^{32}$ where the CJEU concluded that the parent company necessarily determined the commercial policies to its wholly owned subsidiary without any additional burden of proof for the EC other than the detention of shares. The same presumption was also applied when the parent had almost the totality of the subsidiary's capital. ${ }^{33}$

\section{2[a] Extending the presumption of decisive control to the totality of the subsidiary's voting rights}

In Akzo, the CJEU clearly established the rebuttable presumption of the parent's decisive influence upon its wholly owned subsidiaries based on the single economic undertaking doctrine: "it is for the parent company to put before the Court any evidence relating to the economic and legal organisational links between its subsidiary and itself which in its view are apt to demonstrate that they do not constitute a single economic entity." "34 In her Opinion in Akzo, the Advocate General ("AG") Kokott stated that "the decisive factor is whether the parent, by reason of the intensity of its influence, can direct the conduct of its subsidiary to such an extent that the two must be regarded as one economic unit." 35 She emphasised that the absence of a single commercial policy can be established only on the basis of an assessment of the totality of all the economic, organisational and legal links which tie the parent and the subsidiary. This presumption allows the EC to hold the parent company liable for the subsidiary's conduct by simply proving that the parent company owns

\footnotetext{
Österreich and Others and Siemens Transmission \& Distribution Ltd and Others v European Commission [2014] ECLI:EU:C:2014:256 para 45. Also, "there is no requirement, in order to impute to a parent company liability for the acts undertaken by its subsidiary, to prove that that parent company was directly involved in, or was aware of, the offending conduct. It is not because of a relationship between the parent company and its subsidiary in instigating the infringement or, a fortiori, because the parent company is involved in the infringement, but because they form a single undertaking for the purposes of Article 81 EC that the Commission is able to address the decision imposing fines to the parent company" see Case T-77/08 The Dow Chemical Company v European Commission [2012] ECLI:EU:T:2012:47 para 106; Nada Ina Pauer, The single economic entity doctrine and corporate group responsibility in European antitrust law (Wolters Kluwer 2014).

${ }^{30}$ Dyestuffs, (IV/26.267) Commission Decision 69/243/EEC [1969] OJ L195/11.

31 Case 48-69 Imperial Chemical Industries Ltd. v Commission of the European Communities [1972] ECLI:EU:C:1972:70 paras 132-134 ; Wils Wouters, The Optimal Enforcement of EC Antitrust Law (Kluwer Law International 2002).

${ }^{32}$ Case 107/82 Allgemeine Elektrizitäts-Gesellschaft AEG-Telefunken AGv Commission of the European Communities [1983] ECLI:EU:C:1983:293 para 50.

${ }^{33}$ Case T-168/05 Arkema SA v Commission of the European Communities [2009] ECLI:EU:T:2009:367 para 70

${ }^{34}$ Case C-97/08 P Akzo Nobel NV and Others v Commission of the European Communities [2009] ECLI:EU:C:2009:536 para 65.

${ }^{35}$ Case C-97/08 P Akzo Nobel NV and Others v Commission of the European Communities [2009] ECLI:EU:C:2009:262 Opinion of AG Kokott para 93 ; Benjamin Cheynel, 'La responsabilité des sociétés mères du fait de leurs filiales' in Valerie Giacobbo-Peyronnel, Christophe Verdure (eds), Contentieux du droit de la concurrence de l'Union européenne (Bruylant 2017).
} 
all or almost all of the shares of the subsidiary. The case-law has also applied the presumption when two shareholders each hold $50 \%$ of a subsidiary. ${ }^{36}$

In Goldman Sachs, the detention of the totality of voting rights associated with the subsidiaries shares, despite a minority holding of its capital during the post-IPO period, is equated with the detention of the totality or almost totality of its capital because of the degree of control of the parent over the subsidiary implied in those cases. The two situations entail, therefore, the same legal consequence, i.e. the EC can rely on the presumption that the parent company actually exercises decisive influence over its subsidiary's market conduct.

\section{2[b] Exercising decisive influence through the involvement in the subsidiary's day-to-day operations}

In cases where the presumption cannot be applied, i.e. where the parent company holds only a minority stake in the subsidiary's capital, the EC bears the burden of proof that the parent was in a position to exercise decisive influence over the subsidiary's conduct, as well as, that the parent did actually exercise that influence. The EC can use all factual evidence including "in particular any management power." ${ }^{37}$ In Fuji, it was upheld that such an influence was actually exercised by the parent company which was a minority stakeholder with rights greater than those normally granted to minority shareholders in order to protect their financial interests. Those rights, when evaluated in the light of a set of consistent legal or economic indicia, were such as to show that a decisive influence was exercised over the subsidiary's market conduct. In Toshiba, ${ }^{39}$ the parental liability was attached to a minority stake with veto rights that went beyond the normal rights of minority shareholders.

In Goldman Sachs, the minority capital of the financial investor was coupled with management powers to (i) appoint the members of the subsidiary's boards of directors, (ii) call the subsidiary's shareholder meetings, (iii) propose the removal of board members or of all boards of directors of the subsidiary, (iv) have a relevant role in the boards of directors and (v) receive regular updates and monthly reports from the subsidiary. On the one hand, the attachment of parental liability because of the above-mentioned management oversight seems to follow the same line as the Fuji and Toshiba case-law and the single economic undertaking rationale. However, on the other hand, it cancels de facto the possibility for financial investors, may they be institutional investors, private equity firms or investment banks as partners of equity firms, to create value in their portfolio companies through corporate engineering and management practices. Involvement in the day-to-day operations entails the risk of imputing joint and several parental liability to investors for EU antitrust infringements committed by their portfolio companies.

\footnotetext{
${ }^{36}$ Case T-314/01 Coöperatieve Verkoop- en Productievereniging van Aardappelmeel en Derivaten Avebe BA v Commission of the European Communities [2006] ECLI:EU:T:2006:266.

${ }_{37}$ Case T-314/01 Coöperatieve Verkoop- en Productievereniging van Aardappelmeel en Derivaten Avebe BAv Commission of the European Communities [2006] ECLI:EU:T:2006:266 para 36.

${ }^{38}$ Case T-132/07 Fuji Electric Co. Ltd (anciennement Fuji Electric Holdings Co. Ltd) v European Commission [2011] ECLI:EU:T:2011:344, para 183.

${ }^{39}$ Case C-623/15 P Toshiba Corp. v European Commission [2017] ECLI:EU:C:2017:21 paras 107-113.
} 


\subsection{THE EU LIABILITY REGIME FOR ANTITRUST INFRINGEMENTS COMMITED BY A SUBSIDIARY}

So far, the EU case-law is quite strict when finding the parent companies liable for their subsidiaries' competition law infringements. Arguments from parent companies based on measures they took to discourage or eliminate anticompetitive behaviour by their subsidiaries have been rejected by the Courts. Disregarded instructions of the parent company to the subsidiary's sole manager to not to proceed with anticompetitive agreements, ${ }^{40}$ adoption of internal guidelines, code of conduct and audits performed by a compliance officer in order to avoid competition violations ${ }^{41}$ or even setting up formal written policies for compliance with competition law ${ }^{42}$ have not, so far, succeeded at exonerating parent companies. When those initiatives were decided by the investors and imposed on the portfolio companies, they were considered to be proof of the investors' control over the companies. Any investor's involvement in the subsidiary's management, even if it doesn't concern the day-to-day operations will most likely be interpreted as an element of exercising a decisive influence over the subsidiary's conduct in the market, hence constituting a single economic unit with it.

The ECN+ Directive, ${ }^{43}$ aiming at empowering the national competition authorities in their missions, encourages the imposition of effective, proportionate and dissuasive fines on undertakings and associations of undertakings where, intentionally or negligently, they infringe Article 101 or 102 TFEU. Financial investors are, much like the classical industrial owners, exposed not only to fines but to actions for damages as well. ${ }^{44}$ The difference is, though, that in the case of financial investors the range of countries in which an action can be brought against them is much larger. That could encourage any claimants' forum shopping intentions. A financial investor holds a variety of portfolio companies, throughout the period it is operational in the market. Thus, it is highly probable he might be liable for the anticompetitive behaviour of portfolio companies more than once. In that case, the investor would be considered as a repeat infringer ${ }^{45}$ risking heavier penalties because of that aggravating circumstance. ${ }^{46}$

In the aftermath of Goldman Sachs, financial investors must be vigilant in regards to management oversight by limiting their direct responsibility for board decisions and avoiding

${ }^{40}$ C-155/14 P Evonik Degussa GmbH and AlzChem AG v European Commission [2016] ECLI:EU:C:2016:446 para 15.

${ }^{41}$ Case T-138/07 Schindler Holding Ltd and Others v European Commission [2011] ECLI:EU:T:2011:362 para 88.

${ }^{42}$ Cases T-141/07, T-142/07, T-145/07 and T-146/07, General Technic-Otis Sàrl (T-141/07), General Technic

Sarl (T-142/07), Otis SA and Others (T-145/07) and United Technologies Corporation (T-146/07) v European Commission [2011] ECLI:EU:T:2011:363 para 85.

${ }^{43}$ Directive (EU) 2019/1 of the European parliament and of the Council of 11 December 2018 to empower the competition authorities of the Member States to be more effective enforcers and to ensure the proper functioning of the internal market (Text with EEA relevance) [2019] OJ L/11, recital 46, art. 13. ${ }^{44}$ Directive 2014/104/EU of the European parliament and of the Council of 26 November 2014 on certain rules governing actions for damages under national law for infringements of the competition law provisions of the Member States and of the European Union (Text with EEA relevance) [2014] OJ L/349, recital 37, art. 11.

${ }^{45}$ Wils Wouter, "Recidivism in EU Antitrust Enforcement: A Legal and Economic Analysis" [2012] World

Competition 5; Ludovic Bernardeau, Nils Wahl, La récidive en droits de la concurrence (Bruylant 2017)

${ }^{46}$ Guidelines on the method of setting fines imposed pursuant to Article 23(2)(a) of Regulation No 1/2003

(Text with EEA relevance) [2006] OJ C/210. 
the receipt of any unnecessary financial and management information from portfolio companies that may be linked to day-to-day operations. ${ }^{47}$ Before the acquisition of a portfolio company, it would be useful for the investors to verify if the company has its own compliance programmes, codes of conduct in order to prevent competition law violations and training programs for its employees; if the investors impose those measures to a company that itself has none of those measures implemented, the investors' good intentions may backfire as the EC and the Courts may view them as an involvement in the conduct of the subsidiary. The due diligence process should be stricter in regards to any pre-existing antitrust problem. According to the findings, investors and portfolio companies can further negotiate the purchase price and draft clearer investment and exit agreements with specific clauses in case of competition law infringements, e.g. clauses allocating liability, allocating between the parties the fine's payment that could be imposed jointly and severally on them, clauses extending the indemnity liability to cover any civil damages awards and costs, etc. ${ }^{48}$ After the acquisition, competition law audits in a regular basis can help identify immediate and potential threats. Investors always have the option to take procedural steps when an EU competition law infringement can be identified during the due diligence and/or the audits, like the leniency application ${ }^{49}$ which can be a very useful tool in the hands of proactive financial investors. ${ }^{50}$

\section{CONCLUSION}

The rationale behind parental liability in EU competition law has always been a thorny subject for both academics and practitioners. Despite the arguments of parent undertakings, the single economic entity doctrine rarely allows a parent company to be exonerated for an infringement committed by its subsidiaries. The presumption that the parent has in fact exercised decisive influence over the subsidiary in cases where the parent has total ownership of the voting rights means that the EC has no need to recourse to any factual criteria in order to attach parental liability. In cases where the parent does not hold the totality of shares or voting rights, the EC can establish the exercise of decisive influence over the market conduct

\footnotetext{
${ }^{47}$ Financier Worldwide, 'Parent company liability in Europe' (2014).

$<$ https://www.financierworldwide.com/parent-company-liability-in-europe > accessed 27 February 2021 ; WilmerHale LLP, 'Antitrust and Competition: Investment Firms' Voting Rights - The Devil is in the Potential Antitrust Liability’ (2021) < https://www.wilmerhale.com/en/insights/client-alerts/20210201antitrust-and-competition-investment-firms-voting-rights-the-devil-is-in-the-potential-antitrust-liability $>$ accessed 27 February 2021.

48 Paul Hastings LLP, 'EU Court Ruling Highlights Antitrust Risks for Investment Funds' (2021)

<https://www.paulhastings.com/insights/client-alerts/eu-court-ruling-highlights-antitrust-risks-forinvestment-funds $>$ accessed 27 February 2021 ; Dechert LLP, 'EU Court of Justice: Financial Investors Liable for Anticompetitive Conduct of Portfolio Companies' (2021),

$<$ https://www.dechert.com/knowledge/onpoint/2021/1/eu-court-of-justice--financial-investors-liable-foranticompetit.html > accessed 27 February 2021 ; Squire Patton Boggs, 'Mitigating EU Antitrust Liability Risk in Private Equity Deals', (2021), <https://www.squirepattonboggs.com/-

/media/files/insights/publications/2021/02/mitigating-eu-antitrust-liability-risk-in-private-equitydeals/privateequitydealsalert.pdf $>$ accessed 27 February 2021.

${ }^{49}$ Commission Notice on Immunity from fines and reduction of fines in cartel cases (Text with EEA relevance) [2006] OJ C/298.

${ }^{50}$ Baskaran Balasingham, The EU Leniency Policy : Reconciling Effectiveness and Fairness (Wolters Kluwer 2016); Emma Salemme, Enforcing European Competition Law Through Leniency Programmes in the Light of Fundamental Rights- With an Overview of the US Leniency Programme (Nomos Verlag 2019).
} 
of its subsidiary, that is therefore not acting autonomously, by means of other evidence, e.g. the involvement of the parent in the subsidiary's day-to-day management regarding its operational business or the parent's strategic control over the subsidiary's general corporate structure through the appointment of senior managers with or without personal links to the parent company, budget and business plan oversight or regular reporting obligations.

The Goldman Sachs case seems to ignore the operational specificities of financial investors and equates them with industrial owners of subsidiaries. In doing so, the investors' operational model of managing investments by creating value through a more effective management and corporate governance for a short period of time is seriously challenged. Furthermore, private equity firms can be exposed to fines as well as to damages claims for EU competition law infringements that the portfolio company may have started to commit many years before its acquisition and has continued to do so, after the acquisition, with or without the private equity's firm knowledge of this ongoing infringement. Due diligence, audits, compliance programmes, contractual agreements between investors and companies taken place before the acquisition, so that they may not be considered as an involvement in the portfolio company's operational business or corporate structure, as well as use of leniency programmes if an infringement is uncovered can help the pro-active financial investors to weather the EU antitrust storm. 


\section{LIST OF REFERENCES}

Balasingham B, The EU Leniency Policy: Reconciling Effectiveness and Fairness (Wolters Kluwer 2016)

Barber F, Goold M, 'The Strategic Secret of Private Equity' (2007) Harvard Business Review 53

DOI: https://doi.org/10.1108/sd.2008.05624bad.003

Bernardeau L, Wahl N, La récidive en droits de la concurrence (Bruylant 2017)

Bloom N, Sadun R, Reenen van J, 'Do private equity owned firms have better management practices?' (2015) American Economic Review 442

DOI: https://doi.org/10.1257/aer.p20151000

Boggs P Sq, 'Mitigating EU Antitrust Liability Risk in Private Equity Deals' (2021)

Available at: https://www.squirepattonboggs.com/-

/media/files/insights/publications/2021/02/mitigating-eu-antitrust-liability-risk-inprivate-equity-deals/privateequitydealsalert.pdf

Cheynel B, 'La responsabilité des sociétés mères du fait de leurs filiales' in Valerie GiacobboPeyronnel, Christophe Verdure (eds), Contentieux du droit de la concurrence de l'Union européenne (Bruylant 2017)

Dechert LLP, 'EU Court of Justice: Financial Investors Liable for Anticompetitive Conduct of Portfolio Companies' (2021)

Available at: https://www.dechert.com/knowledge/onpoint/2021/1/eu-court-of-justice-financial-investors-liable-for-anticompetit.html

Fenn G, Liang N, Prowse S, 'The Economics of the Private Equity Market’ (1996) Fed. Res. Bull. 26

Financier Worldwide, 'Parent company liability in Europe' (2014)

Available at: https://www.financierworldwide.com/parent-company-liability-in-europe

Fontenay de E, 'Private equity firms as gatekeepers' (2013) Rev. Banking \& Fin. L. 115 DOI: https://doi.org/10.2139/ssm.2245156

Gompers P, Kaplan S, Mukharlyamov V, 'What do private equity firms say they do?' (2016) Journal of Financial Economics 449

DOI: https://doi.org/10.3386/w21133 
Kaplan S, Strömberg P, 'Leveraged Buyouts and Private Equity’ (2009) J.Econ.Persp. 121

DOI: $\underline{\text { https://doi.org/10.3386/w14207 }}$

Kenyon H (ed), 'Preqin Special Report: Banks as Investors in Private Equity' (2012)

Available at:

https://docs.preqin.com/reports/Preqin Special Report Banks as Investors in Private Equity.pdf

Koening C, 'Comparing Parent Company Liability in EU and US Competition Law' (2018) World Competition 70

Lossen U, Portfolio Strategies of Private Equity Firms-Theory and Evidence, (Deutscher UniversitätsVerlag 2007)

DOI: https://doi.org/10.1007/978-3-8350-9428-4

Matheson J, 'The modern law of corporate groups: An empirical study of piercing the corporate veil in the parent-subsidiary context' (2008) NCL Rev. 1091

Pauer N, The single economic entity doctrine and corporate group responsibility in European antitrust law (Wolters Kluwer 2014)

Paul Hastings LLP, 'EU Court Ruling Highlights Antitrust Risks for Investment Funds' (2021)

Available at: https://www.paulhastings.com/insights/client-alerts/eu-court-ruling-

highlights-antitrust-risks-for-investment-funds

Salemme E, Enforcing European Competition Law Through Leniency Programmes in the Light of Fundamental Rights- With an Overview of the US Leniency Programme (Nomos Verlag 2019)

DOI: https://doi.org/10.5771/9783845297170

Tracy E, 'Imputed Liability: How to Determine When Parent Companies Should Be Held Liable for the Patent Infringements of Their Subsidiary Companies' (2017) Mo. L. Rev. 82

WilmerHale LLP, 'Antitrust and Competition: Investment Firms' Voting Rights — The Devil is in the Potential Antitrust Liability' (2021)

Available at: https://www.wilmerhale.com/en/insights/client-alerts/20210201-antitrustand-competition-investment-firms-voting-rights-the-devil-is-in-the-potential-antitrust$\underline{\text { liability }}$

Wouter W, 'Recidivism in EU Antitrust Enforcement: A Legal and Economic Analysis' (2012) World Competition 5

Wouters W, The Optimal Enforcement of EC Antitrust Law (Kluwer Law International 2002) 
Wright M, Amess K, Weir C, et al. 'Private equity and corporate governance: Retrospect and prospect’ (2009) Corporate Governance: An International Review 353 